the coast but the intervening area is covered by fluvio-glacial deposits. If these exposures are part of the same body, then a pluton having a minimum length of $\mathbf{2 . 5}$ $\mathrm{km}$ must be added to the known occurrences. The pluton is composed of hornblende peridotite of the same type as that forming the main body on Amitsoq. About $1 \%$ of sulphides are disseminated throughout the peridotite.

A reconnaissance of the supracrustal rocks in the northern part of the peninsula between Sermilik and Tasermiut fjords showed that the metaconglomerates outcropping there carry small amounts of sulphides, mainly chalcopyrite.

\title{
References
}

Berrangé, J. P. 1970: The geology of two small layered hornblende peridotite (picrite) plutons in South Greenland. Bull. Gronlands geol. Unders. 92 (also Meddr Grønland 192, 1), 43 pp. Schönwandt, H. K. 1971: Mineralised ultramafic rocks in South Greenland. Rapp. Grønlands geol. Unders. 35, 30-31.

Mineralogisk Institut, Danmarks Tekniske Høiskole, Bygn. 204, 2800 Lyngby, Denmark.

\section{FIELD MAPPING AND GEOPHYSICAL WORK IN THE SCORESBY SUND REGION, EAST GREENLAND}

\section{Niels Henriksen}

The fourth season of the five-year mapping programme in the Scoresby Sund region was carried out in July and August. A tent base camp was established at the head of Hurry Inlet and served as operation centre for 3 helicopters. The Norwegian sealer "Brandal", and a small cutter provided transport in the fjords. The expedition members numbered 44, comprising 16 geological two-man parties and supporting personnel. Five parties mapped in the crystalline complex of Liverpool Land and one party the Caledonian supracrustal and igneous rocks on Canning Land. Mapping of the post-Caledonian sediments in Jameson Land and southern Scoresby Land was undertaken by six parties (see Birkelund and Perch-Nielsen, this report). Two parties mapped the eastern part of the Tertiary basalt area south of Scoresby Sund and one undertook Quaternary investigations in the central and eastern part of the Scoresby Sund region. A geophysical party carried out a terrestrial magnetometer investigation across central Jameson Land and a shipborne investigation in Scoresby Sund and Hall Bredning.

Approximately $2500 \mathrm{~km}^{2}$ were mapped in the Caledonian crystalline complex and about $4500 \mathrm{~km}^{2}$ were mapped and remapped in the post-Caledonian sediments. In the south approximately $2000 \mathrm{~km}^{2}$ of Tertiary basalts were investigated. 


\section{The crystalline complex in Liverpool Land}

Systematic mapping in Liverpool Land was begun in 1969 by R. F. Cheeney (Univ. of Edinburgh) and K. Coe (Univ. of Exeter) who distinguished a sequence of older gneisses and a younger post-kinematic granite in the south-western part of the area (Henriksen \& Higgins, 1970). In 1971 the investigations were extended to the remainder of Liverpool Land, J. D. Friderichsen, N. Henriksen and A. K. Higgins joining R. F. Cheeney and K. Coe in the mapping.

The crystalline complex comprises three main areas of metamorphic rocks, whose relationships to each other are uncertain, and a suite of pre- to post-kinematic plutonic rocks.

\section{Metamorphic rocks}

One of the principal areas occupies much of the northern half of Liverpool Land and is formed by a sequence, at least $8 \mathrm{~km}$ thick, of dark homogeneous hornblendebiotite gneisses, strongly migmatised gneisses and a metasedimentary group of schists and gneisses with prominent marbles and quartzies. All the rocks have suffered high-grade regional metamorphism, and the southern and western parts are heavily migmatised. At least two phases of minor isoclinal folds and a subsequent major, more open folding have been recognised.

The second area of metamorphic rocks occurs in the eastern part of central Liverpool Land and was first described Kranck (1935). The rocks are largely non-migmatitic and outcrop in a large-scale dome structure (Bütler, 1948). The sequence comprises coarsely banded hornblende-biotite gneisses overlain by a metasedimentary sequence.

The third area occupies the southernmost part of Liverpool Land. Here a sequence of metasediments, gneisses and "granitic" gneisses are largely flat-lying or gently northerly-dipping. No major fold closures have been observed.

\section{Plutonic rocks}

A suite of probably interrelated pre-, late and post-kinematic plutonic rocks occupies extensive parts of central and southern Liverpool Land. In places the oldest rocks have gradual transitions to the surrounding metamorphic rocks, but in most cases clear cross-cutting relations exist. The oldest plutonites are two large bodies of hornblende-quartz monzonites, with local foliation. A number of biotitehornblende-bearing, sometimes feldspar-porphyritic, medium- to coarse-grained granites sensu lato and a few quartz-poor intrusions form a group which is intermediate in age. Relatively younger is a large body of fine-grained biotite granite in central Liverpool Land and probably also the Hurry Inlet Granite (Coe, 1971) which has yielded a Caledonian $\mathrm{Rb} / \mathrm{Sr}$ mineral age of $434 \mathrm{~m}$. y. (Hansen \& Steiger, 1971). The youngest acid plutonic rocks form a series of aplite dykes and sheets which are found especially in the northern part of Liverpool Land. 
Later events

Major thrusts are found at several levels in Liverpool Land influencing both metamorphic units and plutonic rocks.

A major unconformity between the crystalline rocks and the overlying Triassic arkoses occurs in western Liverpool Land along the boundary to the Mesozoic Jameson Land basin. The pre-Triassic weathering surface on the crystalline rocks is preserved locally.

Swarms of thin, impersistent biotite-pyroxene lamprophyres occur in southern Liverpool Land and doleritic dykes of probable Tertiary age up to $15-20 \mathrm{~m}$ wide occur scattered throughout Liverpool Land.

\section{Caledonian rocks on Canning Land and Wegener Halvø}

The north-eastern part of Canning Land and Wegener Halvø, known from the work of Bütler (1948) and Noe-Nygaard (1937), was remapped by R. Caby, (Cen. Rech. Fac. Sci., Montpellier) who made a detailed investigation of the Eleonore Bay sediments and discovered an Eocambrian tillite and a sequence of Cambrian strata. In total, a sequence of more than $6000 \mathrm{~m}$ thickness was recorded.

Early Devonian sediments and a sequence of acid volcanics rest with angular unconformity on the deformed Caledonian sediments. These volcanics pre-date the intrusion of a large granite sensu lato.

\section{The plateau basalts}

Activity was concentrated in the region between Kap Stevenson and Kap Brewster on the south side of Scoresby Sund. The mapping was carried out by two field parties led by C. H. Emeleus (Univ. of Durham) and W. S. Watt (GGU). Particular attention was paid to the relationship between the Kap Brewster sediments and the coastal flexure in the plateau basalts. A succession from sea level to $1900 \mathrm{~m}$ was established with the stratigraphically lowest flows at sea level near Kap Stevenson in the north-western part of the area and the highest flows on the nunataks to the south-east.

Emphasis was put on the lateral extent and correlation of single flows and flow groups. In the north-western and inland parts of the area the flows are horizontal or dip slightly to the south-east, while in the coastal region, where the basalts are affected by a coastal fault system, south-easterly dips up to $35^{\circ}$ were measured. Petrographically the basalts are very homogeneous, mostly fine-grained and slightly porphyritic.

Palaeomagnetic field work using a hand compass was carried out as in previous years.

The geological setting of some warm springs at Rømer Fjord on the Blosseville Kyst and at Kap Tobin was briefly investigated, and samples of gas and water were collected. 


\section{Quaternary}

Quaternary deposits and features were studied by S. Funder (Univ. of Copenhagen) in the Carlsberg Fjord-Hurry Inlet area and in southern Jameson Land.

Extensive areas on the high plateau of southern Jameson Land are covered by drift deposits. Investigations near the highest part of the plateau at $800 \mathrm{~m}$ above sea level showed the drift to be approximately $30 \mathrm{~m}$ thick. Half of the boulders in the drift were erratic crystalline blocks indicating the far-travelled character of the drift cover.

A persistent ridge up to $90 \mathrm{~m}$ high can be traced for about $40 \mathrm{~km}$ along the south coast of Jameson Land. This ridge, described as "The Highway" (Aldinger, 1935), is formed of undisturbed layered silt and sand deposits with locally a thin till cover. Shell fragments occur in places in the silt. The ridge is interpreted as an ice marginal feature of probable Weichsellian age.

Shorelines are found at $30-40 \mathrm{~m}$ above sea level in Hurry Inlet and up to $25 \mathrm{~m}$ above sea level at the head of Carlsberg Fjord. This suggests that Hurry Inlet probably became free of ice before Carlsberg Fjord.

Material for radiometric age determination was collected from shell-bearing deposits and from drill core samples from a few post-glacial deposits.

\section{Magnetic survey}

A magnetic survey conducted by T. Bidstrup (Univ. of Copenhagen) was divided into terrestrial and ship-borne phases. During the first phase magnetic profiles were established across the central parts of the Mesozoic sedimentary Jameson Land basin and the bordering Caledonian crystalline complexes. The aim of these investigations was to obtain geophysical evaluation of the thickness of the sediments.

The determination of the southern extension of the sediments and their border relation to the Tertiary basalts in the south was the aim of the ship-borne phase. Investigations were made along several profile lines across Hall Bredning and Scoresby Sund.

A special investigation in Fønfjord was aimed at identifying the possible existence of Tertiary volcanic vents predicted by investigations of the surrounding basalts.

The geophysical data are in the course of evaluation and no final results are available at the time of writing.

\section{References}

Aldinger, H. 1935: Geologische Beobachtungen im Oberen Jura des Scoresbysundes (Ostgrönland). Meddr Gronland 99, 1, 128 pp.

Bütler, H. 1948: Notes on the geological map of Canning Land (East Greenland). Meddr Gronland 133, 2, 97 pp.

Coe, K. 1971: Faulting in the western part of Liverpool Land, East Greenland. Bull. geol. Soc. Denmark 20, 260-264. 
Hansen, B. T. \& Steiger, R. H. 1971: The geochronology of the Scoresby Sund area. Progress report I: $\mathrm{Rb} / \mathrm{Sr}$ mineral ages. Rapp. Gronlands geol. Unders. 37, 55-57.

Henriksen, N. \& Higgins, A. K. 1970: Preliminary results of mapping in the crystalline complex of Renland, the southern Stauning Alper and south-west Liverpool Land, Scoresby Sund, East Greenland. Rapp. Grønlands geol. Unders. 30, 5-17.

Kranck, E. H. 1935: On the crystalline complex of Liverpool Land. Meddr Grønland 95, 7, $122 \mathrm{pp}$.

Noe-Nygaard, A. 1937: Die palaeozoischen Eruptivgesteine von Canning Land. Meddr Grønland 118, 6, $153 \mathrm{pp}$.

\title{
FIELD MAPPING OF PALAEOZOIC, MESOZOIC AND TERTIARY SEDIMENTS IN THE SCORESBY SUND REGION, EAST GREENLAND
}

\author{
Tove Birkelund and Katharina Perch-Nielsen
}

An eight-week field season concluded the four-year mapping project on the Phanerozoic sediments of the Scoresby Sund region. Six teams worked in Scoresby Land, Jameson Land, Liverpool Land and the Kap Brewster area (see Henriksen, this report). In addition to the authors the following took part in the 1971 mapping: R. G. Bromley, U. Asgard, F. Surlyk (Univ. of Copenhagen), M. Aellen (Eidg. Techn. Höchschule, Zurich), J. H. Callomon (Univ. of London) and K. Birkenmajer (Polish Acad. Sci., Krakow).

In Scoresby Land one party revised the map of Gurreholm Bjerge, printed but not yet published, which was prepared by $M$. Aellen. Here the Upper Permian locality with Cyclolobus found in 1957 by Aellen, was revisited and new material collected. At this locality, the Upper Permian-Lower Triassic boundary is rather indistinct. Special attention was paid to the Triassic red beds, gypsum and sedimentary structures. A paper by Perch-Nielsen, Birkenmajer, Birkelund and Aellen on the revised stratigraphical subdivision of the Triassic sequence is in preparation. Short visits were paid to scattered localities in both Scoresby Land and Jameson Land to fill gaps in the previous years' mapping.

On Wegener Halvø the map by Grasmïck and Trümpy (1969) was revised. Sediments of the Eleonore Bay Group and the Devonian Cape Fletcher volcanics were found along Fleming Fjord in the middle part of the peninsula faulted against Devonian sandstones and siltstones. The Upper Permian overlies the folded and faulted Devonian with an angular unconformity that can be observed in several places. A polygenetic basal conglomerate to breccia occurs locally at the base of the Upper Permian limestones. The overlying, dark Posidonia shales are only present in small basins between reefs and are overlain by limestones with 